Article

\title{
The Effect of CSR Environmental Initiatives on Purchase Decisions-A Cross-Regional Study in Poland and Ukraine
}

\author{
Joanna Sawicka (1) and Elżbieta Marcinkowska * (1)
}

Faculty of Management, AGH University of Science and Technology, 30-059 Krakow, Poland; sawicka@agh.edu.pl

* Correspondence: emarcink@zarz.agh.edu.pl

Citation: Sawicka, J.;

Marcinkowska, E. The Effect of CSR Environmental Initiatives on Purchase Decisions-A Cross-Regional Study in Poland and Ukraine. Sustainability 2022, 14, 2590. https://doi.org/ $10.3390 /$ su14052590

Academic Editor: Mohammad Nurunnabi

Received: 7 December 2021 Accepted: 21 February 2022 Published: 23 February 2022

Publisher's Note: MDPI stays neutral with regard to jurisdictional claims in published maps and institutional affiliations.

Copyright: (C) 2022 by the authors. Licensee MDPI, Basel, Switzerland. This article is an open access article distributed under the terms and conditions of the Creative Commons Attribution (CC BY) license (https:// creativecommons.org/licenses/by/ $4.0 /)$.

\begin{abstract}
To engage in an effective corporate social responsibility (CSR) action, it is necessary to first recognise its impact on targeted buyers. This study surveyed respondents from Poland and Ukraine to analyse their perception of initiatives related to environmental protection and the effect of such initiatives on purchasing behaviour. The study demonstrated how consumers' age, education level, or professional position influence their purchasing decisions and feedback on different kinds of CSR actions related to environmental protection. Of the five areas identified in the questionnaire (environmental protection, cooperation with the local community, corruption and bribery, labour and employment, and human rights), environmental protection was found to be the most important to consumers. These results may help in decision making regarding specific environmental CSR initiatives targeted at selected social groups living in this region of Europe.
\end{abstract}

Keywords: corporate social responsibility; CSR initiatives; environmental protection; consumer purchasing decision; Central Europe

\section{Introduction}

Environmental protection has become one of the main global discussions in recent years. The depletion of natural resources and increasing levels of pollution are compelling societies to act for the protection and effective management of these resources. Currently, CSR is perceived as an important tool in corporate image building [1,2] and maintaining relationships with stakeholders, including consumers [3]. Moreover, the implementation of CSR results in financial benefits [4-6]. More and more companies are deciding to conduct their own CSR policies and report them publicly [7]. Real CSR efforts can range from symbolic to substantive CSR commitment [8]. A recent survey of the top 100 global firms suggested that CSR actions consisted mainly of cosmetic changes or rebranding [9]. Such symbolic use of CSR is referred to as greenwashing and carries the risk of negative stakeholder reaction over time [10].

As one of the leading CSR issues, environmental protection has already been studied in many countries. However, the literature has mainly been concerned with environmentally friendly products in terms of consumer demographic characteristics, product knowledge, price and quality, or perceived reliability [11-14]. There is a lack of broader analyses relating to the issue of environmental protection; for example, analyses that identify the proenvironmental actions perceived and evaluated by consumers and their effects on consumers' purchase choices.

Rahman and Norman [15] showed that consumers demonstrate more favourable attitudes towards a firm when they learn that its CSR activities are directed towards local beneficiaries. These attitudes manifest in the form of better intentions to acquire the product, as well as the willingness to pay premium prices for it. The relationship between CSR programs and consumer behaviour was also confirmed by Dang and Nguyen [16], who suggested that companies may also invite consumers to participate in their environmental activities. Policymakers may find it difficult to identify the areas of green engagement that 
are most expected by stakeholders. Given a variety of options, company boards should choose only the highest-rated actions and initiatives for further implementation.

To provide the necessary knowledge, our study aimed to fill the research gap in determining whether environmentally motivated CSR activities influence purchasing decisions of consumers living in Poland and Ukraine. This area was chosen because of the historical and current cultural, social, and economic ties that exist that resulted from the formation of national borders in the past and the current economic migration of the population in this area. An additional motivation for conducting research in this region was the fact that, to the best of the authors' knowledge, there are only a few publications on CSR from a consumer perspective in this part of Europe [17-20]. The lack of relevant literature and research conducted in this part of Europe makes it difficult for company managers to make choices about environmental practices expected by local residents (potential customers of companies). Therefore, our findings can provide managers with valuable information on selected environmental factors of CSR in the context of consumer attitudes. In addition, the paper examines the motivational effects of environmental CSR initiatives while taking into account consumers' age, education level, and work experience. This information can also help companies targeting a specific customer segment to decide how to shape their CSR.

The paper is structured as follows. Section 2 presents the definition of CSR adopted for the purpose of the paper, the theoretical background for the conducted research, and the problems of environmental CSR against the background of selected Central European countries. Section 3 presents the research hypotheses. Section 4 discusses the research method, including the sample selection. Section 5 presents the research results and a discussion. The final section contains the conclusions, along with the limitations of the study and suggestions for further research.

\section{Literature Review}

\subsection{Corporate Social Responsibility}

The issue of environmental protection fits into the model of CSR, the origins of which date back to the publication of the Brundtland report entitled Our Common Future, which concluded that global sustainable development must 'ensure that it meets the needs of the present without compromising the ability of future generations to meet their own needs' [21]. Since then, many definitions, sometimes very different, have been proposed [22]. In this research, we adopted the CSR concept corresponding to the European Commission definition as 'enterprises' responsibility for their impact on the society' [23]. According to this concept, enterprises should have a mechanism for integrating social, environmental, ethical, and human rights issues, as well as consumer concerns about their operations and core strategies. CSR should at least cover human rights issues, labour and employment practices, environmental issues, and strategies to combat bribery and corruption. All related actions should be taken in close cooperation with the parties concerned to maximise the creation of common values for their owners and shareholders, as well as other parties involved [23]. CSR can be considered a viable competitive advantage, since it can strengthen a firm's sustainability image and brand [24,25].

\subsection{CSR, Stakeholders, Consumer}

This study was based on the stakeholder theory, which states that organisations gain from understanding the needs and concerns of a wide range of stakeholders [26] because they have a significant influence on the achievement of the organisation's goals [27,28]. Considering stakeholder expectations translates into growth for the company [29]. The objectives of different stakeholder groups are often conflicting, making it difficult for a company to achieve them. Although all stakeholder groups should be treated equally based on the stakeholder theory, in practice, the priority in realizing expectations often depends on the strength of the stakeholders' influence on the business. Hence, the frequent division in the literature on direct (primary, internal) stakeholders-customers, suppliers, employees, 
and shareholders-and indirect (secondary, external) stakeholders-local communities, governments, and the general public [30,31].

This division indicates the hierarchy of importance of stakeholder groups. As previously mentioned, although the stakeholder theory is based on a normative assumption of balance in meeting stakeholder needs, it also acknowledges that firms should serve the interests of key groups to ensure their continued support [29]. From the point of view of companies and the operational goals they want to achieve, customers (consumers) are one of the key stakeholder groups upon which the volume of sales realised depends [32]. Furthermore, this group is sensitive to CSR activities [33]. Expenses incurred on CSR activities aimed at consumers can bring in returns for the company in a short period of time [32]. Therefore, companies can profit from undertaking CSR activities for this stakeholder group. Consumers' satisfaction with products and services translates into their loyalty in purchase decisions. They make purchase decisions based on functional benefits related to product/service features, psychological benefits related to a person's emotional well-being, and their own personal values [34]. It has been found that consumers are more likely to become personally attached to [35] and oppose criticism against companies using CSR practices [36].

\subsection{Environmental CSR in Central Europe}

Enterprises, in particular, pay a lot of attention to environmental responsibility in terms of CSR. As PricewaterhouseCoopers [37] showed, a company's environmental performance can become a dominant theme in CSR reporting. Moreover, KPMG reports [7,38] showed that the percentage of companies in the CSR report that have reduced carbon emissions increased from 58\% in 2015 to $76 \%$ in 2020. In Poland, 96\% of large and medium-sized companies believe that it is the duty of business to respond to social and environmental challenges. Every second respondent declared that from the point of view of their company, environmental protection is the most important challenge [39]. CSR reporting rates in Poland among large enterprises increased from 59\% in 2017 to $77 \%$ in 2020 . The SME sector is also actively involved in the implementation of CSR activities. The 2019 survey confirmed that as many as $67 \%$ of these companies were implementing activities in this area [40].

A high level of social acceptance for compliance with standards concerning the environment can improve a firm's relationships with its stakeholders and gain their support, thereby achieving better business conditions [41,42]. Moreover, a company can significantly improve its overall reputation [43-45] and competitive advantage [46,47]. There exists positive feedback between a company's sensitivity to environmental problems and consumer loyalty. A consumer with positive attitudes towards both environmental sustainability and green advertising is more likely to purchase environmentally friendly products [48-50].

Nowadays, the need for proenvironmental activities has been recognised worldwide by companies from different industries and by consumers [51-53]. A total of $57 \%$ of Poles indicated poor air quality as the biggest environmental problem in their country. They placed waste pollution in second place (48\%) [53]. An affirmative attitude to environmental responsibility is the result of many factors. Elements such as governmental financial support, current political situations, or long-term traditions arising directly from national cultural and social backgrounds have a decisive impact on the environmental decisions made by entrepreneurs [22,54]. The geopolitical location in which an enterprise operates also cannot be ignored. The general public and industry representatives are more likely to engage in environmental actions in regions where concern for preserving the environment has long enjoyed considerable political and financial support, such as in the Nordic countries $[55,56]$. Central Europe has only relatively recently begun to pay attention to environmental issues [55].

In different Central European countries, the routes to nationwide environmental protection are not identical. In Estonia, most CSR initiatives have not been supported by public authorities. CSR there is still seen only as corporate philanthropy, sponsorship, 
and/or marketing activities, rather than responsibility towards stakeholders. Emerging CSR programs are a result of Estonian society becoming more mature and the country's economic situation more stable [57]. In Poland, the existing law enforces and/or motivates companies to undertake proenvironmental behaviours [58,59]. As many as $75 \%$ of Polish companies have included ecology in their strategies, and $67 \%$ are already active in this area. More importantly, $61 \%$ of them declared that the activities undertaken in favour of the environment did not result from imposed regulations, but was their sovereign decision. Only $2 \%$ of enterprises indicated legal requirements as forcing them to take proenvironmental activities [60]. The development of CSR in Poland is boosted by consumer expectations (71\%) [61]. They usually avoid buying products from companies that may negatively impact society or the environment $(56 \%)$, analyse and evaluate the products they buy in this regard (53\%), and are aware that their purchasing decisions can have a real impact on changes in the world (38\%) [61]. Generally, the CSR leaders in Poland are state-owned enterprises effectively supported by the government [62]. Contrastingly, incentives for CSR development in Ukraine come from the business sector, rather than from society. They are primarily undertaken by subsidiaries of multinational corporations. The Ukrainian society's demand for responsible initiatives is relatively low [63].

Environmental initiatives are indicated as key in the assessment of the company $[17,18,39,64]$. Consumers' sensitivity to CSR is directly related to the tendency of companies to engage in CSR activities [65,66]. However, the literature includes examples that confirm that not all CSR initiatives have the same impact on consumer satisfaction $[64,67]$. Consumers perceive corporate commitment to environmental protection as critical if potential environmental damage is likely to affect future generations [68]. Companies planning the CSR policy must take into account the consumer's attitudes towards environmental protection.

Green consumers believe that individual consumers can effectively protect the environment through their choices [48]. A survey of undergraduate students at a university in the southern United States found that $13 \%$ were willing to spend up to $50 \%$ more on certain products because they were green [69]. In Poland, 22\% of surveyed residents declared their willingness to pay a higher price for green products [53]. The more strongly such consumers perceive themselves as acting for the environment, the higher their intention to purchase green products [14]. Research on ecolabelling has demonstrated that consumers in general mostly tend to look for information on the product's environmental impact on its labels $[70,71]$ because it is the most convenient way to 'be green', given their increasingly busy lifestyles. Nevertheless, explaining purchase motivations is not a simple task. For example, the need for companies to reduce harmful emissions, particularly $\mathrm{CO}_{2}$, has been demonstrated in a study of consumer perceptions related to CSR [68,72]. Still, although consumers consider energy-efficient technologies as important, this belief is not always the exclusive decision-making factor that determines their ultimate action. The mere knowledge of the environment does not necessarily influence the purchase of fuel-efficient vehicles, for example [73]. A decision to buy green products is more likely to be made if it is associated with enhancing the buyer's social reputation, which is often the case when buying a hybrid car [74].

To meet consumer expectations, many companies have changed their operating strategies to actively respond to environmental problems and changes in consumer attitudes. This is reflected in the content of published reports on CSR activities [75].

\section{Hypotheses Development}

This study was motivated by the observed growing social awareness surrounding the existing correlation between consumer choices and the state of the environment in Central Europe. A natural consequence of this conclusion was the need to determine whether CSR activities undertaken by companies in the field of environmental protection (further referred to as environmental CSR) matter to the consumers living in this area of Europe. 
As already mentioned, the conducted research adopted the CSR definition proposed by the European Commission [23], which includes the main areas of environmental protection, local community, fight against corruption and bribery, labour and employment practices, and human rights. Therefore, the first step in the research was to assess the position of environmental CSR in the respondents' priority scale. The next step was to determine which among the environmental CSR initiatives are most appreciated by consumers and have the strongest impact on their purchasing decisions; these activities are presented below in Section 4. Only a few studies devoted to this issue have dealt with Central Europe.

To address this knowledge gap, this study proposed to verify the following research hypotheses:

H1: The impact of environmental CSR initiatives on consumer purchase decisions depends on the type of action taken.

For H1, the zero and the alternative hypotheses were formulated as:

H0: Regardless of the type of environmentally oriented CSR action, purchasing decisions remain unchanged.

HA: CSR environmental initiatives affect purchasing decisions depending on the type of action taken.

To more closely investigate the influence of specific factors on $\mathrm{H} 1$, auxiliary hypotheses (also having zero and alternative hypotheses) were worded as:

H2: The consumer's age is important in the assessment of environmental CSR initiatives.

H3: The consumer's education is important in the assessment of environmental CSR initiatives.

H4: The consumer's professional position is important in the assessment of environmental CSR initiatives.

\section{Materials and Methods}

This study analysed some of the data collected as a result of wider research on the perception of CSR information that enterprises address to different audiences. The study was conducted in the form of a survey in the first half of 2020 on a sample of 872 people, aged 18 to 75, from both Poland and Ukraine. The choice of respondents in the population was not accidental. They lived in two cities of similar size-Krakow and Lviv. Currently, these cities are in southwestern Poland and Western Ukraine. However, the cultural proximity of their inhabitants is closer than it may seem. For almost six centuries, these cities were part of the same states or political systems-the 14th-century Kingdom of Poland, 19th-century Austro-Hungarian Empire, early 20th-century Republic of Poland, and the second era of the communist systems dominated by the Soviet Union. Although they have been part of two different countries for the last 30 years, mutual contacts and cultural exchange between them are still active due to the significant number of temporary economic migrants who emigrated from Western Ukraine to Poland. Indeed, such a population of respondents can be considered representative of the city dwellers on the northern side of the Carpathians. Today, this region is popularly referred to by the common name Galicia, used when it was one of the provinces of the Austro-Hungarian Empire.

Table 1 presents the sociodemographic profile of the research sample. The criteria for division among the respondents were the characteristics of nationality, gender, education, place of residence, age (divided into four generational groups according to the year of birth), and occupational profile. 
Table 1. Demographic profile of the respondents.

\begin{tabular}{ccccc}
\hline & Demographic Data & Abbreviation & Number of Responses & Percentage of Responses \\
\hline \multirow{2}{*}{ Nationality } & Poland & Pl & 473 & $56.58 \%$ \\
& Ukrainian & Uk & 360 & $43.06 \%$ \\
& Other & O & 3 & $0.36 \%$ \\
\hline \multirow{2}{*}{ Gender } & Woman & $\mathrm{W}$ & 480 & $57.42 \%$ \\
& Man & $\mathrm{M}$ & 356 & $42.58 \%$ \\
\hline Education & Vocational/Primary & $\mathrm{V}$ & 32 & $3.83 \%$ \\
& Secondary & $\mathrm{S}$ & 133 & $15.91 \%$ \\
& Higher & $\mathrm{U}$ & 671 & $80.26 \%$ \\
\hline \multirow{2}{*}{ Generation } & Baby Boomers (1945-1964) & $\mathrm{BB}$ & 95 & $11.36 \%$ \\
& Generation X (1965-1980) & $\mathrm{X}$ & 189 & $22.61 \%$ \\
& Generation Y (1981-1994) & $\mathrm{Y}$ & 129 & $15.43 \%$ \\
& Generation Z (1995-2000) & $\mathrm{Z}$ & 423 & $50.60 \%$ \\
\hline
\end{tabular}

The survey questionnaire was divided into two parts (A and B). Part A consisted of auxiliary questions to classify respondents by nationality, age, education level, and professional profile, among other characteristics. Part B was composed of questions directly concerning CSR. They were organised in blocks devoted to five areas: human rights, labour and employment, corruption and bribery, cooperation with the local community, and environmental issues. The questionnaire was prepared in two languages (Polish and Ukrainian).

The following activities within the environmental CSR areas were selected as potentially important for the respondents, and were therefore extensively developed in the questions of the survey:

(1) Reduction in $\mathrm{CO}_{2}$ emissions;

(2) Selective waste collection and reduction in the amount of generated waste;

(3) Implementation of energy-efficient technologies (e.g., LED lighting, environmentally friendly air conditioning, energy-efficient production lines) and investment in renewable energy (e.g., solar panels, wind power plants);

(4) Environmentally friendly transport (electric and hybrid cars, railways, coaches, and other mass transport);

(5) Infrastructure for cyclists (shelters, racks, changing rooms);

(6) Offering environmentally friendly products and ecolabelling (the company meets higher environmental standards than legally required).

Such choices seem to be universal on national and international scales [75]. Many of these initiatives are subject to legal regulations at the European Union level, as well as the legal system in force in Poland. Thus, they constitute a universal platform for social discussions on environmental protection and related research $[48,70,76]$.

At first, respondents were asked to indicate the CSR areas considered important for their purchasing decisions as consumers. They were allowed to choose more than one option. Areas not selected were labelled as 'unimportant'. In the block concerning environmental CSR, the participants assessed different proecological initiatives by rating them on a 5-point Likert scale, where 1 meant 'unimportant' and 5 meant 'very important'.

The sample selection was purposive. It was completed using the snowball method. Questionnaires were distributed to students of each of the largest academic centres in Poland (Krakow) and Ukraine (Lviv). These centres have a cultural impact on the entire geographical region in question. The surveyed students gave further copies of the questionnaire to people in the environments in which they worked and functioned, and to members of their families. For obvious reasons, it was assumed that the people included in the snowball method influenced each other in shaping their views and consumer attitudes [77]. The choice of this method was based on the desire to test consumer attitudes in the study region. Previous research confirmed [15] that consumers showed more favourable attitudes towards a company when they learned that its CSR activities targeted local beneficiaries. 
A total of 872 questionnaires were collected; 36 were rejected due to various errors or omissions. The research hypotheses were tested in the framework of standard statistical techniques using Microsoft Excel 2019 and IBM SPSS Statistics 26.0 software.

The Kruskal-Wallis H test was used to compare three or more groups in terms of scores. To compare the evaluation of the actions, an analysis was carried out using the Friedman rank test. For the analyses, $\alpha=0.05$ was assumed as the level of significance. The analyses included nomparametric tests due to the ordinal nature of the scale. Necessary corrections for variations in population size were applied.

\section{Results and Discussion}

The choice of proenvironmental CSR activities as the subject of the analysis was not accidental. The study showed that there was a statistically significant difference in the evaluation of selected CSR areas: $\chi^{2}(2)=255.192, p<0.001$ (Table 2). Environmental CSR was the most important factor in consumers' purchasing decisions.

Table 2. Comparison of assessments of CSR activities in consumers' purchasing decisions.

\begin{tabular}{|c|c|c|c|c|c|c|}
\hline \multirow{2}{*}{ Activity } & \multicolumn{2}{|c|}{ Value } & \multicolumn{2}{|c|}{ Proportion [\%] } & \multirow{2}{*}{$\chi^{2}(4)$} & \multirow{2}{*}{$p$} \\
\hline & 0 & 1 & 0 & 1 & & \\
\hline Environmental protection & 351 & 305 & 53.51 & 46.49 & & \\
\hline Cooperation with the local community & 414 & 242 & 63.11 & 36.89 & & \\
\hline Combating corruption and bribery & 525 & 131 & 80.03 & 19.97 & 255.192 & $<0.001$ \\
\hline Employees & 576 & 80 & 87.80 & 12.20 & & \\
\hline Human rights & 408 & 248 & 62.20 & 37.80 & & \\
\hline
\end{tabular}

$\chi^{2}$-Cochran's $Q$ test statistic; $p$ —test probability; 0—unimportant; 1 -important.

Environmental protection was indicated by $46.49 \%$ of respondents, ahead of the other CSR areas (Figure 1).

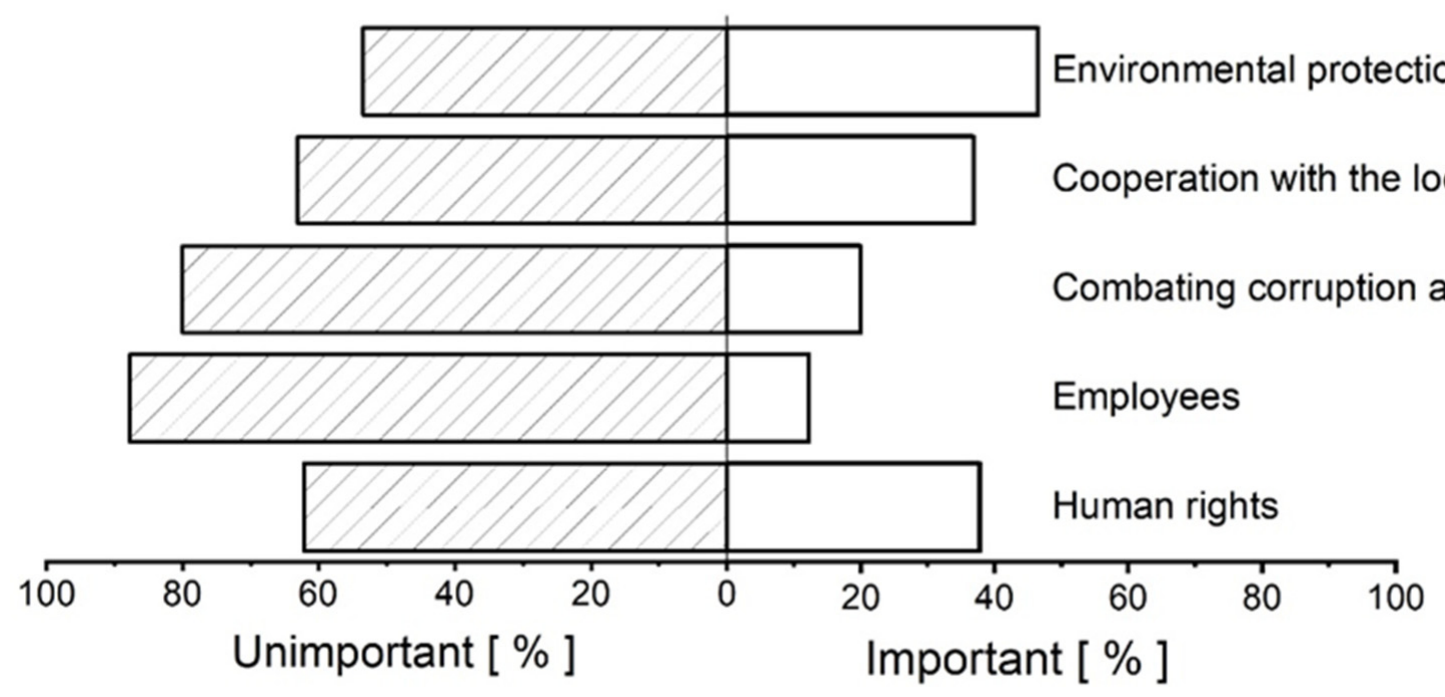

Figure 1. Assessment of CSR areas.

Bar charts illustrating the respondents' preferences for particular actions are shown in Figure 2. 


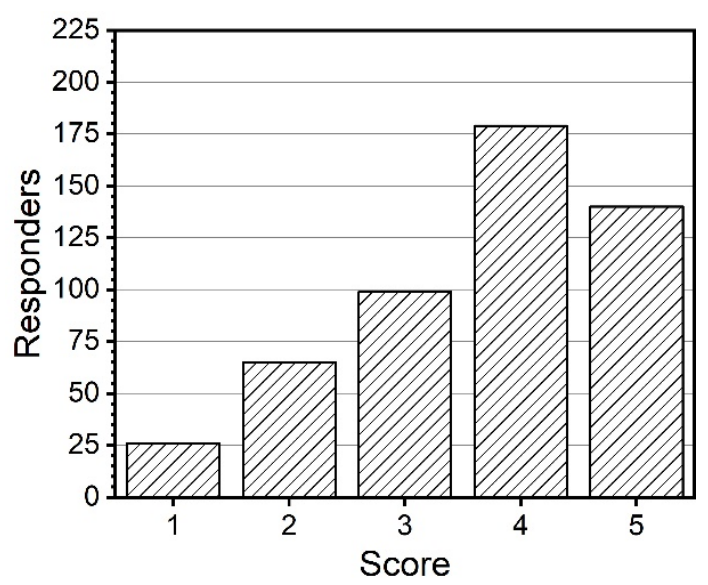

(a)

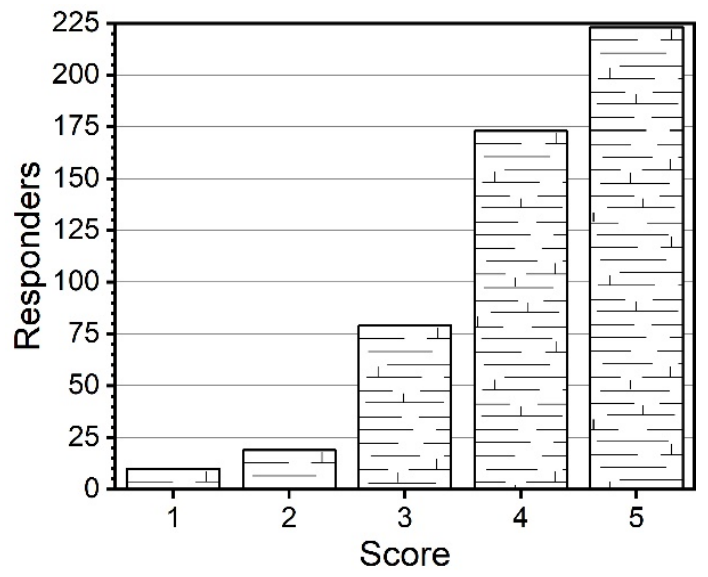

(c)

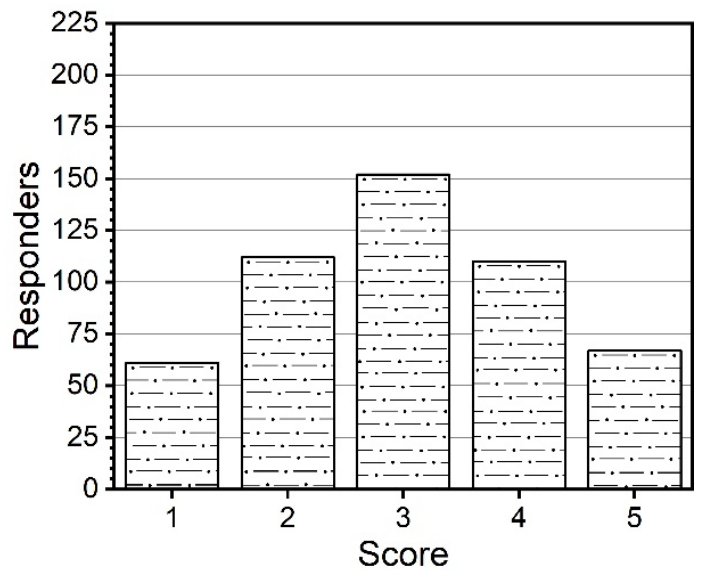

(e)

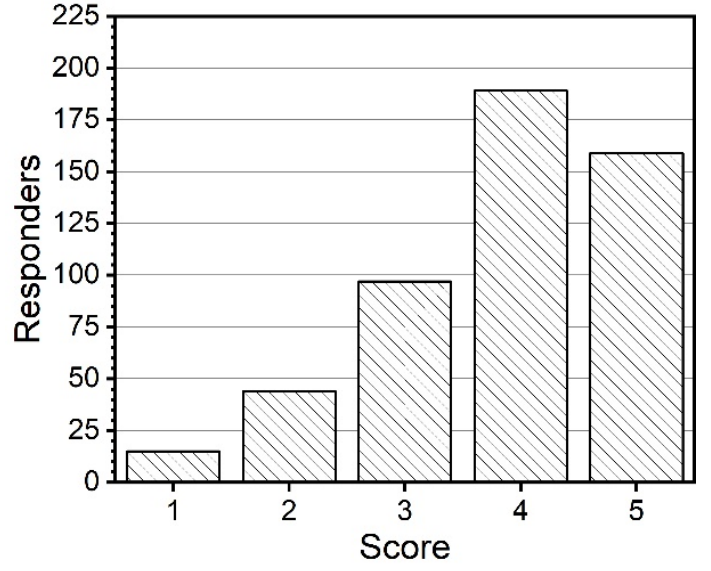

(b)

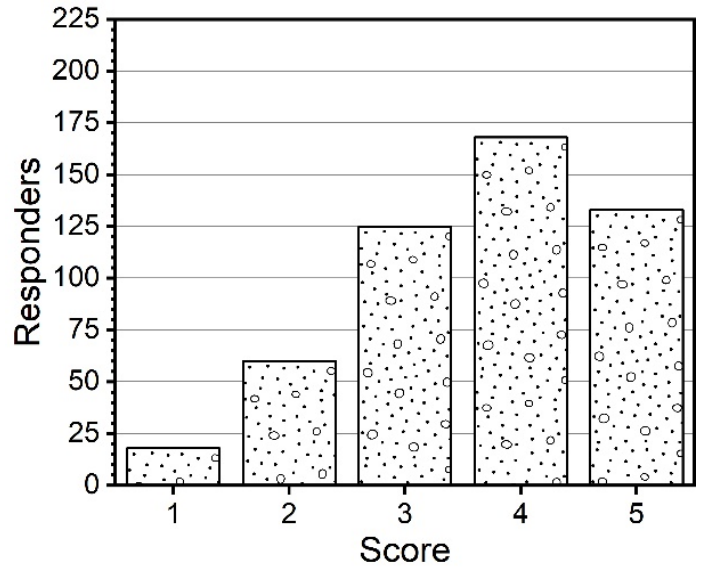

(d)

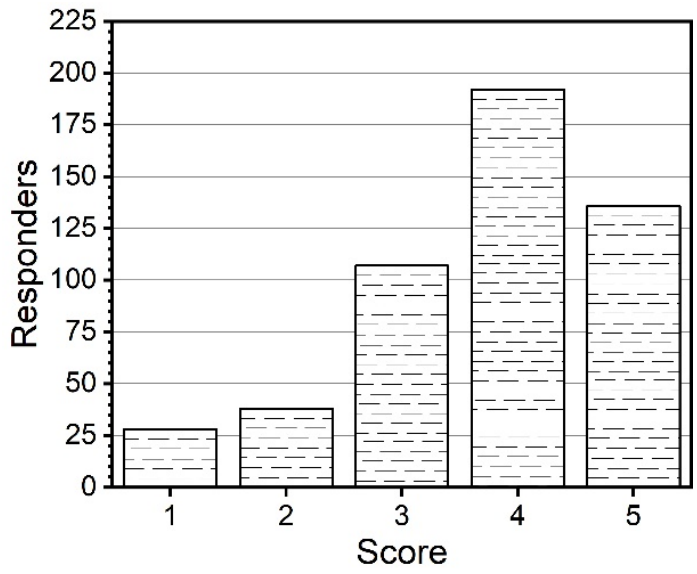

$(\mathbf{f})$

Figure 2. Assessment of different environmental CSR actions: (a) reduction in $\mathrm{CO}_{2}$ emissions; (b) selective waste collection; (c) implementation of energy-efficient technologies; (d) environmentally friendly transport; (e) infrastructure for cyclists; (f) environmentally friendly products. The abscissa refers to the score assessed, and the ordinate to the number of respondents who made this assessment.

In-depth analysis allowed for an investigation into environmental CSR in terms of the impact of specific activities. The data were subjected to a variance analysis with a repeatedmeasures Friedman test. This analysis demonstrated statistically significant differences in the assessments of a company's actions. Calculating $\chi^{2}(5)=123.37$ with $p<0.001$ 
together with the effect size $W=0.04$ allowed the rejection of the zero hypothesis, assuming no differences in the assessments. A post hoc analysis by Dunn's test with a Bonferroni correction for multiple comparisons evidenced statistically significant differences in the perceived importance of each action.

It was concluded from Table 3 that selective waste collection and a reduction in $\mathrm{CO}_{2}$ emissions were the most important to respondents. These were followed by environmentally friendly products and energy-efficient technologies. Environmentally friendly transport was visibly less important. The list ends with infrastructure for cyclists, which lagged by $20 \%$.

Table 3. Comparison of assessments of the environmental CSR activities in consumers' purchasing decisions.

\begin{tabular}{|c|c|c|c|c|}
\hline Action & Mean Rank & $\chi^{2}(5)$ & $p$ & $W$ \\
\hline Selective waste collection & 3.83 & \multirow{6}{*}{123.37} & \multirow{6}{*}{$<0.001$} & \multirow{6}{*}{0.04} \\
\hline Reduction in $\mathrm{CO}_{2}$ emissions & 3.78 & & & \\
\hline Environmentally friendly products & 3.58 & & & \\
\hline Energy-efficient technologies & 3.44 & & & \\
\hline Environmentally friendly transport & 3.27 & & & \\
\hline Infrastructure for cyclists & 3.09 & & & \\
\hline
\end{tabular}

The order of action assessments in this ranking formed a new pattern when the age and education of the respondents were taken into account. The surveyed population was divided into age groups according to the commonly accepted generational cohort theory [78]. This theory distinguishes between people born in 1945-1964 (baby boomers-BB), 19651980 (Generation X), 1981-1994 (Generation Y), and 1995-2000 (Generation Z). The few who were surveyed belonging to the 'Silent Generation', born in 1928-1945, were merged with generation BB. Similarly, the population was categorised by education level (i.e., Vvocational qualifications or lower, S-secondary school graduates, U- university degree or university students) and independently by the type of occupation (i.e., entrepreneurs, management staff, specialists, other employees, students, and retirees). Interviewees classified as 'entrepreneurs' were SME owners. Data in these groups were analysed using the Kruskal Wallis H test, then a Dunn's post hoc analysis with a Bonferroni correction of the significance level was carried out.

The results of the statistically analysed assessment of different environmental actions in the four age groups are presented in Table 4. Assuming no differences between the generations with regard to all the assessments, the results allowed the firm rejection of the hypotheses. The influence of the effect on the differences was negligible. Statistically significant differences existed between Generations $\mathrm{Z}$ and $\mathrm{Y}$ regarding reduction in $\mathrm{CO}_{2}$ emissions, energy-efficient technologies, environmentally friendly transport, and infrastructure for cyclists. For all these actions, higher assessments were given by respondents from Generation Z compared with those from Generation Y. In addition, people from Generation $\mathrm{Z}$ gave higher assessments of reduction in $\mathrm{CO}_{2}$ emissions, selective waste collection, environmentally friendly transport, and infrastructure for cyclists compared with respondents from Generation X. 
Table 4. Assessment of a company's actions in the field of environmental protection by respondents grouped by age.

\begin{tabular}{|c|c|c|c|c|c|c|c|}
\hline \multirow{2}{*}{ Action } & $\mathrm{BB}(n=95)$ & $X(n=189)$ & $Y(n=129)$ & $\mathrm{Z}(n=423)$ & \multirow{2}{*}{$H(3)$} & \multirow{2}{*}{$p$} & \multirow{2}{*}{$\eta^{2}$} \\
\hline & Mean Rank & Mean Rank & Mean Rank & Mean Rank & & & \\
\hline Reduction in $\mathrm{CO}_{2}$ emissions & 309.99 & 284.42 & 297.87 & 356.83 & 19.98 & $<0.001$ & 0.03 \\
\hline Selective waste collection & 315.38 & 280.85 & 305.65 & 354.99 & 18.67 & $<0.001$ & 0.03 \\
\hline Energy-efficient technologies & 323.79 & 308.40 & 288.35 & 348.14 & 10.48 & 0.015 & 0.02 \\
\hline $\begin{array}{l}\text { Environmentally friendly } \\
\text { transport }\end{array}$ & 306.85 & 282.23 & 296.47 & 358.60 & 21.78 & $<0.001$ & 0.03 \\
\hline Infrastructure for cyclists & 337.41 & 284.00 & 288.23 & 354.80 & 19.72 & $<0.001$ & 0.03 \\
\hline $\begin{array}{l}\text { Environmentally friendly } \\
\text { products }\end{array}$ & 331.11 & 299.30 & 309.80 & 344.16 & 7.05 & 0.070 & 0.01 \\
\hline
\end{tabular}

$H$-Kruskal-Wallis test statistic; $p$ —test probability; $\eta^{2}$ —size of effect; $n$-group size.

The results of the statistically analysed assessment of different environmental actions in the groups categorised by respondents' level of education are summarised in Table 5. The hypothesis assuming no differences in the evaluation of the actions according to education level was rejected in the case of the assessments of reduction in $\mathrm{CO}_{2}$ emissions and environmentally friendly transport. The influence of the effect on the differences was weak.

Table 5. Assessment of a company's actions in the field of environmental protection by respondents grouped by education level.

\begin{tabular}{|c|c|c|c|c|c|c|}
\hline \multirow{2}{*}{ Action } & $\mathrm{V}(n=32)$ & $S(n=133)$ & $\mathrm{U}(n=671)$ & \multirow{2}{*}{$H(2)$} & \multirow{2}{*}{$p$} & \multirow{2}{*}{$\eta^{2}$} \\
\hline & Mean Rank & Mean Rank & Mean Rank & & & \\
\hline Reduction in $\mathrm{CO}_{2}$ emissions & 368.81 & 281.82 & 334.95 & 7.82 & 0.020 & 0.02 \\
\hline Selective waste collection & 331.10 & 292.78 & 334.53 & 4.19 & 0.123 & 0.01 \\
\hline Energy-efficient technologies & 350.74 & 299.94 & 332.54 & 2.80 & 0.247 & 0.01 \\
\hline Environmentally friendly transport & 297.62 & 275.33 & 338.82 & 9.99 & 0.007 & 0.02 \\
\hline Infrastructure for cyclists & 305.38 & 289.02 & 336.17 & 5.46 & 0.065 & 0.01 \\
\hline Environmentally friendly products & 324.81 & 300.24 & 333.49 & 2.62 & 0.269 & 0.01 \\
\hline
\end{tabular}

$H$-Kruskal-Wallis test statistic; $p$ — test probability; $\eta^{2}$ —size of effect.

It was found that people with a higher or vocational education profile scored more on the reduction in $\mathrm{CO}_{2}$ emissions and environmentally friendly transport compared with respondents who only attained secondary education. All the groups being compared did not differ in terms of the assessments concerning the other actions.

The statistic of assessments according to the professional activities of respondents is presented in Table 6. The hypothesis assuming no differences in the assessment between respondents from different professional groups was rejected in the case of all the actions, except environmentally friendly products. The influence of the effect on the differences was insignificant. 
Table 6. Assessment of a company's actions in the field of environmental protection by respondents grouped by type of professional activity. Within each category, respondents are listed in descending order of mean rank.

\begin{tabular}{|c|c|c|c|c|c|}
\hline Action & Professional Position & Mean Rank & $H(5)$ & $p$ & $\eta^{2}$ \\
\hline $\begin{array}{l}\text { Reduction in } \mathrm{CO}_{2} \\
\text { emissions }\end{array}$ & $\begin{array}{c}\text { Students }(\mathrm{n}=291) \\
\text { Management staff }(\mathrm{n}=70) \\
\text { Other employees }(\mathrm{n}=201) \\
\text { Specialists }(\mathrm{n}=174) \\
\text { Retirees }(\mathrm{n}=62) \\
\text { Entrepreneurs }(\mathrm{n}=38)\end{array}$ & $\begin{array}{l}361.02 \\
330.62 \\
315.05 \\
298.98 \\
298.30 \\
283.30\end{array}$ & 15.31 & 0.009 & 0.03 \\
\hline $\begin{array}{l}\text { Selective waste } \\
\text { collection }\end{array}$ & $\begin{array}{c}\text { Management staff }(\mathrm{n}=70) \\
\text { Students }(\mathrm{n}=291) \\
\text { Other employees }(\mathrm{n}=201) \\
\text { Retirees }(\mathrm{n}=62) \\
\text { Specialists }(\mathrm{n}=174) \\
\text { Entrepreneurs }(\mathrm{n}=38)\end{array}$ & $\begin{array}{l}369.90 \\
354.40 \\
312.63 \\
311.59 \\
293.81 \\
290.92 \\
\end{array}$ & 15.23 & 0.009 & 0.03 \\
\hline $\begin{array}{c}\text { Energy-efficient } \\
\text { technologies }\end{array}$ & $\begin{array}{l}\text { Management staff }(n=70) \\
\text { Students }(n=291) \\
\text { Retirees }(n=62) \\
\text { Other employees }(n=201) \\
\text { Entrepreneurs }(n=38) \\
\text { Specialists }(n=174)\end{array}$ & $\begin{array}{l}360.36 \\
356.11 \\
337.84 \\
316.62 \\
284.34 \\
282.99\end{array}$ & 17.49 & 0.004 & 0.04 \\
\hline $\begin{array}{l}\text { Environmentally } \\
\text { friendly transport }\end{array}$ & $\begin{array}{c}\text { Students }(\mathrm{n}=291) \\
\text { Management staff }(\mathrm{n}=70) \\
\text { Retirees }(\mathrm{n}=62) \\
\text { Other employees }(\mathrm{n}=201) \\
\text { Specialists }(\mathrm{n}=174) \\
\text { Entrepreneurs }(\mathrm{n}=38)\end{array}$ & $\begin{array}{l}362.31 \\
339.12 \\
335.43 \\
305.16 \\
298.24 \\
266.44 \\
\end{array}$ & 18.24 & 0.003 & 0.04 \\
\hline $\begin{array}{l}\text { Infrastructure for } \\
\text { cyclists }\end{array}$ & $\begin{array}{c}\text { Management staff }(n=70) \\
\text { Students }(n=291) \\
\text { Retirees }(n=62) \\
\text { Other employees }(n=201) \\
\text { Specialists }(n=174) \\
\text { Entrepreneurs }(n=38)\end{array}$ & $\begin{array}{l}367.16 \\
357.23 \\
328.84 \\
313.39 \\
289.27 \\
266.41\end{array}$ & 18.50 & 0.002 & 0.04 \\
\hline $\begin{array}{l}\text { Environmentally } \\
\text { friendly products }\end{array}$ & $\begin{array}{c}\text { Management staff }(\mathrm{n}=70) \\
\text { Students }(\mathrm{n}=291) \\
\text { Other employees }(\mathrm{n}=201) \\
\text { Retirees }(\mathrm{n}=62) \\
\text { Specialists }(\mathrm{n}=174) \\
\text { Entrepreneurs }(\mathrm{n}=38)\end{array}$ & $\begin{array}{l}349.30 \\
339.24 \\
331.18 \\
322.89 \\
309.21 \\
280.08\end{array}$ & 5.22 & 0.390 & 0.02 \\
\hline
\end{tabular}

$H$-Kruskal-Wallis test statistic; $p$ —- test probability; $\eta^{2}$ - size of effect.

Dunn's post hoc test showed that the opinion of different professional groups was somewhat polarised towards different types of environmental action. Students and management staff were the ones who most favoured all kinds of actions aimed at environmental protection. Contrastingly, entrepreneurs were extremely sensitive to environmental issues. Assessments by specialists, other employees, and retirees fell in the middle range. The order of these professions varied depending on the particular action.

The analysis proved that the studied population as a whole prefers initiatives in the field of selective waste collection and reduction in $\mathrm{CO}_{2}$ emissions. Similarly, the priority given to these activities is also characteristic of other cultures and economic areas. Particularly, waste recycling and minimising the use of disposable packaging increasingly draws the attention of consumers [55,79]. Their awareness of the negative environmental effects of the use of plastics, particularly plastic packaging, was demonstrated in [80]. It was pointed out that consumers were exerting real pressure on supermarkets, which in turn influenced the packaging industry [81]. 
The least important to the surveyed respondents was environmentally friendly transport and the infrastructure for cyclists, which seem to be directly related. This may be due to the fact that the development and maintenance of cycle track networks is usually a local task. Thus, local authorities are principally decisive. Usually, they are not interested in a wide-scale debate on this subject, because direct costs would be paid from already tight budgets. In effect, problems related to bicycle transport are not visible in the public space.

Regarding other issues of environmental CSR, disparities were observed due to age, education level, and occupation. Based on the data in Table 4, both the youngest and the oldest generations were the most favourable to all kinds of environmental CSRs. This observation was in contrast to some reports on other populations living in developed countries. In the USA, those belonging to Generation Z are the most eager to be 'green' [82], while in the UK, the elderly seem to be the most active in this field [83]. The data in Table 4 confirmed that Generation $\mathrm{Z}$ was more sensitive than older respondents to proecological initiatives undertaken by a business. Almost all the areas listed in the questionnaire were assessed higher by young people belonging to this age group. This result was consistent with the research presented in a report conducted among Polish residents [84]. It indicated that consumers from Generation $\mathrm{Z}$ paid more attention than other groups to the social attitudes and responsibilities of the companies whose products they bought. More importantly, they were twice as likely as Millennials to spend more on a product from a company that supported local communities and initiatives. This attitude was not specific to the geographic region. The enthusiasm of Generation Z towards CSR activities implemented by companies also was confirmed in other parts of the world $[11,85]$. Surprisingly, there existed a strong conviction that competing companies implementing CSR projects were motivated principally by the common good.

Logically, support for a reduction in $\mathrm{CO}_{2}$ emissions should be correlated with that for environmental transport. This assumption was valid for the respondents belonging to the most educated group (Table 5, 'U' respondents) and, somewhat surprisingly, those who had only received vocational education (' $\mathrm{V}$ ' respondents). The least favourable assessments were made by respondents with a secondary education ('S' respondents). The socioeconomic realities of the studied region may explain this. People with a secondary education pay more attention to visible attributes of wealth, such as cars. More often than not, they try to give an outward impression as if they belong to a higher social class. That is why they buy used high-end cars. They do not want new, greener ones because those are more modest. Therefore, to avoid mental confusion, they are more likely to deny the need to protect the environment.

Table 6 shows a recurring asymmetry that separated students and managers from entrepreneurs, for whom environmental activities were the least important. A typical SME owner in the studied region must face competition from international companies. Very often, the enterprise is still in the phase of primary capital accumulation. Thus, CSR ranks further down in the hierarchy of importance, and the potential profits it can provide are beyond the company's current strategic horizon. All groups shared the same opinion in the category of environmentally friendly products, at least statistically. Common sense led us to assume that this category was equally important to everyone, regardless of occupation, because it was linked to personal health and well-being.

\section{Conclusions}

Much CSR-related research has been focused on multinational corporations and large domestic companies $[7,38]$. This is mainly due to the fact that these companies extensively report their activities. They are also present in the media. However, CSR is also practiced by medium-sized and small enterprises [53,86].

The theoretical framework of CSR is general and applicable to companies of all sizes. A company can be characterised by multiple perspectives, such as: local or global reach, one or multiple locations, and/or consumer or business orientation [86]. The benefits of local consumer orientation have been confirmed in various studies $[15,16]$. In Poland 
and Ukraine, this topic is still unexplored, although an increasing number of companies operating locally are trying to become socially responsible [53].

In order to fill this gap and to provide information and knowledge to local companies on consumers' perceptions of CSR activities, our study focused on residents of the studied areas, namely Krakow and Lviv. The survey was conducted in the form of a questionnaire and was submitted by 872 people. Finally, 836 questionnaires were analysed, and the remaining 36 were rejected for formal reasons. Questionnaires were distributed to students of the largest academic centres in Poland (Krakow) and Ukraine (Lviv). These centres have a cultural impact on the entire geographical region in question. The surveyed students gave further copies of the questionnaire to people in the environments in which they worked and functioned, and to members of their families. The sample selection was purposive, and was completed using the snowball method. The study was conducted in the first half of 2020. Detailed demographics are shown in Table 1.

The survey considered the five most frequently implemented CSR activities by companies. These relate to environmental protection, activities for the local community, corruption and bribery, labour and employment practices, and human rights issues. These are also widely discussed by both practitioners and researchers. It was evidenced that out of the aforementioned CSR activities, consumers living in the examined part of Central Europe appreciated initiatives related to the environment the most. While the list of environmental actions addressed in the survey may seem short, in reality, it is more nuanced. In addition, consumers were asked to indicate other proenvironmental measures and rank them. Single indications without ranking were omitted in the further (statistical) analysis. We decided to find a balance between the length and detail of the questionnaire by focusing on the activities most discussed in the media and implemented by companies.

Additionally, the hypothesis on the relationship between the type of proenvironmental initiative, being an element of CSR policy implemented by enterprises, and the potential purchase decisions of consumers was confirmed. The initiatives concerning reductions in $\mathrm{CO}_{2}$ emissions and selective waste collection received the highest scores. Other initiatives (energy-efficient technologies, environmentally friendly transport and products, and infrastructure for cyclists) were also identified as important, although they were assigned lower scores. Statistical significance was confirmed for all environmental initiatives surveyed $(p<0.001)$. As already mentioned in the article, expenses incurred on CSR activities aimed at consumers can bring in returns for the company in a short period of time. Thus, companies can take into account all the indicated proenvironmental actions presented in the article. Although consumers considered reductions in $\mathrm{CO}_{2}$ emissions and selective waste collection as particularly important activities, they were not the only proenvironmental factors that determined their purchasing decisions.

The study also confirmed that age, education level, and professional position influenced the perception and evaluation of specific environmental activities. These activities were most appreciated by the youngest and the oldest participants in the survey (generations $\mathrm{Z}$ and $\mathrm{BB}$ ) and by people with higher and vocational educations. Different professional groups gave different ranks to individual proenvironmental activities.

The combination of the type of initiative and the segment of customers using the company's services or products were found to be important. These conclusions are in line with other studies. For example, due to the amount of fossil fuel used by airplanes, airlines will never be perceived as green by their customers, at least in terms of $\mathrm{CO}_{2}$ emissions. However, despite this, environmental factors were not a criterion for selecting planes, and airlines in particular, as a mode of transport [56].

Given the above findings, when deciding on specific environmental initiatives, companies should consider to whom the activities are dedicated and whether they are in line with consumers' expectations for the industry, such as making products with the lowest carbon footprint.

Our research provided a unique insight into the still under-researched Central European consumer community. This study can become a starting point for the effective 
selection of environmental CSR activities tailored to the expectations of consumers living in this region of Central Europe. At the same time, it can provide guidelines for marketers designing channels of marketing communications with potential customers. Every organisation wants to build the kind of relationship with consumers that would encourage them to buy its products for a long time. Implementation of proenvironmental activities appreciated and expected by the target group of customers (selected, for example, by age) can contribute to this. According to a Nielsen report [87], nearly $40 \%$ of Poles already are interested in ecological products. These are both residents of large cities and smaller towns. According to the cited report, young people, but also older consumers, often reach for ecoproducts $(29 \%)$. These results were consistent with our research. Companies can make product-related decisions that lead to reduced environmental impact. They can also use promotional tools to highlight the environmental benefits of their products (e.g., low energy consumption, reduction in waste, use of recycled materials in production, etc.). Companies can also invite consumers to participate in their environmental activities. For example, BNP Paribas Bank in Poland ran a campaign in 2019-2020 in which it pledged to plant an oxytree in exchange for each newly opened cash loan account. This proposal was met with great interest from the bank's customers. About 60,000 trees were planted.

The study presented in this paper was not free of limitations. Firstly, the results should not be generalised to other regions, because the respondents' views and opinions may have been specific to that area only. In order to check this, the survey should be extended to other parts of Poland and Ukraine. However, one should bear in mind that when considering the possible impact of CSR on the local customers, geographical areas that are too large should not be considered, due to the risk of losing the most characteristic influences.

Secondly, the provided list of analysed environmental activities did not include all possibilities. Companies are taking new and different actions to differentiate themselves from others in the competitive market. Nonetheless, the study can serve as an indication of the direction an environmental initiatives in the region should take in order to achieve the desired effect.

Thirdly, the study did not take the price factor into account. We do not know how consumers would behave if they were informed that environmental measures would increase product prices. This issue is interesting, and will be the subject of our further research in the future. However, it should also be borne in mind that it is not always the case that environmental behaviour of companies necessarily results in higher prices of the goods offered. Environmental benefits are usually a plus, but will often be the deciding factor in choosing between products of equal price and quality [88]. We also believe that this paper enriches the literature on consumer preference analysis focused on Central Europe, and provides an impetus for further research in this direction.

Author Contributions: Conceptualization, J.S. and E.M.; methodology, J.S. and E.M.; software, J.S. and E.M.; validation, J.S. and E.M.; formal analysis, J.S. and E.M.; investigation, J.S. and E.M.; resources, J.S. and E.M.; data curation, J.S. and E.M.; writing-original draft preparation, J.S. and E.M.; writing—review and editing, J.S. and E.M.; visualization, J.S. and E.M.; supervision, J.S. and E.M.; project administration, J.S. and E.M.; funding acquisition, J.S. and E.M. All authors have read and agreed to the published version of the manuscript.

Funding: The APC was funded under subvention funds for the Faculty of Management of the AGH University of Science and Technology.

Institutional Review Board Statement: Not applicable.

Informed Consent Statement: Not applicable.

Data Availability Statement: The data presented in this study are available on the request from the authors.

Conflicts of Interest: The authors declare no conflict of interest. 


\section{References}

1. Nan, X.; Heo, K. Consumer responses to corporate social responsibility (CSR) initiatives: Examining the role of brand-cause fit in cause-related marketing. J. Advert. 2007, 36, 63-74. [CrossRef]

2. Sen, S.; Bhattacharya, C.B. Does doing good always lead to doing better? Consumer reactions to corporate social responsibility. J. Mark. Res. 2001, 38, 225-243. [CrossRef]

3. Dowell, G.W.S.; Muthulingam, S. Will firms go green if it pays? The impact of disruption, cost, and external factors on the adoption of environmental initiatives. Strateg. Manag. J. 2017, 38, 1287-1304. [CrossRef]

4. Brulhart, F.; Gherra, S.; Quelin, B.V. Do stakeholder orientation and environmental proactivity impact firm profitability? J. Bus. Ethics 2019, 158, 25-46. [CrossRef]

5. Leonidou, C.N.; Katsikeas, C.S.; Morgan, N.A. "Greening” the marketing mix: Do firms do it and does it pay off? J. Acad. Mark. Sci. 2013, 41, 151-170. [CrossRef]

6. Menguc, B.; Ozanne, L.K. Challenges of the "green imperative": A natural resource-based approach to the environmental orientation-business performance relationship. J. Bus. Res. 2005, 58, 430-438. [CrossRef]

7. KPMG Report: The Road Ahead. The KPMG Survey of Corporate Responsibility Reporting. 2017. Available online: https://home.kpmg/pl/pl/home/insights/2018/02/raport-the-road-ahead-the-kpmg-survey-of-corporate-responsibilityreporting-2017.html (accessed on 11 October 2020).

8. Schons, L.; Steinmeier, M. Walk the talk? How symbolic and substantive CSR actions affect firm performance depending on stakeholder proximity. Corp. Soc. Responsib. Environ. Manag. 2016, 23, 358-372. [CrossRef]

9. Kramer, M.R.; Agarwal, R.; Srinivas, A. Business as Usual Will Not Save the Planet. Available online: https://hbr.org/2019/06/ business-as-usual-will-not-save-the-planet (accessed on 13 February 2021).

10. Parguel, B.; Benoît-Moreau, F.; Larceneux, F. How sustainability ratings might deter 'Greenwashing': A closer look at ethical corporate communication. J. Bus. Ethics 2011, 102, 15. [CrossRef]

11. Ariker, Ç.; Toksoy, A. Generation Z and CSR: Antecedents of purchasing intention of university students. Kafkas Üniversitesi Íktisadi Ve İdari Bilim. Fakültesi Derg. 2017, 8, 483-502. [CrossRef]

12. Chen, T.B.; Chai, L.T. Attitude towards the environment and green products: Consumer's perspective. Manag. Sci. Eng. 2010, 4 27-39. [CrossRef]

13. Joshi, Y.; Rahman, Z. Factors affecting green purchase behaviour and future research directions. Int. Strateg. Manag. Rev. 2015, 3, 128-143. [CrossRef]

14. Mohammed, A.; Homaid, A.; Alaswadi, W. Factors influencing green purchase behaviour among young consumers in Saudi Arabia. Transnatl. Mark. J. 2020, 8, 51-73. [CrossRef]

15. Rahman, F.; Norman, R.T. The effect of firm scale and CSR geographical scope of impact on consumers' response. J. Retail. Consum. Serv. 2016, 28, 189-198. [CrossRef]

16. Dang, V.T.; Nguyen, N.; Pervan, S. Retailer corporate social responsibility and consumer citizenship behavior: The mediating roles of perceived consumer effectiveness and consumer trust. J. Retail. Consum. Serv. 2020, 55, 102082. [CrossRef]

17. Cerkasov, J.; Huml, J.; Vokacova, L.; Margarisová, K. Consumer's attitudes to corporate social responsibility and green marketing. Acta Univ. Agric. Silvic. Mendelianae Brun. 2017, 65, 1865-1872. [CrossRef]

18. Hommerová, D.; Šrédl, K.; Vrbková, L.; Svoboda, R. The perception of CSR activities in a selected segment of McDonald's customers in the Czech Republic and its effect on their purchasing behavior-A case study. Sustainability 2020, 12, 8627. [CrossRef]

19. Spodarczyk, E. An attempt to determine the determinants of an effective impact of corporate social responsibility on consumer behaviour. A pilot study report. Management 2019, 23, 64-79. [CrossRef]

20. Stávková, J.; Stejskal, L.; Toufarová, Z. Factors influencing consumer behaviour. Agric. Econ. 2008, 54, 276-284. [CrossRef]

21. WCED Report of the World Commission on Environment and Development: Our Common Future. Available online: https: / / digitallibrary.un.org/record/139811\#record-files-collapse-header (accessed on 15 May 2021).

22. Dahlsrud, A. How corporate social responsibility is defined: An analysis of 37 definitions. Corp. Soc. Responsib. Environ. Manag. 2008, 15, 1-13. [CrossRef]

23. European Commission. A Renewed EU strategy 2011-14 for Corporate Social Responsibility. COM 681. 2011. Available online: https:/ / www.eurocommerce.eu/media/7237/position-csr-renewed_csr_strategy_2011-14-07.03.2012.pdf (accessed on 12 September 2021).

24. Amores-Salvadó, J.; Castro, G.M.; Navas-López, J.E. Green corporate image: Moderating the connection between environmental product innovation and firm performance. J. Clean. Prod. 2014, 83, 356-365. [CrossRef]

25. Ben Youssef, K.; Leicht, T.; Pellicelli, M.; Kitchen, P.J. The importance of corporate social responsibility (CSR) for branding and business success in small and medium-sized enterprises (SME) in a business-to-distributor (B2D) context. J. Strateg. Mark. 2018, 26, 723-739. [CrossRef]

26. Freeman, R.E. Strategic Management: A Stakeholder Approach; Pitman Publishing: Boston, MA, USA, 1984; ISBN 0273019139.

27. Parmar, B.L.; Freeman, R.E.; Harrison, J.S.; Wicks, A.C.; Purnell, L.; de Colle, S. Stakeholder theory: The state of the art. Acad. Manag. Ann. 2010, 4, 403-445. [CrossRef]

28. Fifka, M.; Loza Adaui, C. Managing Stakeholders for the Sake of Business and Society. In New Perspectives on Corporate Social Responsibility; O’Riordan, L., Zmuda, P., Heinemann, S., Eds.; Springer Gabler: Wiesbaden, Germany, 2015; pp. 71-87, ISBN 978-3-658-06794-6. 
29. Donaldson, T.; Preston, L.E. The Stakeholder Theory of the corporation: Concepts, evidence, and implications. Acad. Manag. Rev. 1995, 20, 65-91. [CrossRef]

30. Nellis, J.; Parker, D. Principles of Business Economics; Prentice Hall: London, UK, 2006.

31. Turker, D. Measuring corporate social responsibility: A scale development study. J. Bus. Ethics 2009, 85, 411-427. [CrossRef]

32. Dawkins, C. Agonistic pluralism and stakeholder engagement. Bus. Ethics Q. 2015, 25, 1-28. [CrossRef]

33. Bhattacharya, C.B.; Sen, S. Consumer-company identification: A framework for understanding consumers relationships with companies. J. Mark. 2003, 67, 76-88. [CrossRef]

34. Bhattacharya, C.B.; Korschun, D.; Sen, S. Strengthening stakeholder-company relationships through mutually beneficial corporate social responsibility initiatives. J. Bus. Ethics 2008, 85, 257-272. [CrossRef]

35. Du, S.; Bhattacharya, C.B.; Sen, S. Reaping relational rewards from corporate social responsibility: The role of competitive positioning. Int. J. Res. Mark. 2007, 24, 224-241. [CrossRef]

36. Klein, J.; Dawar, N. Corporate social responsibility and consumers' attributions and brand evaluations in a product-harm crisis. Int. J. Res. Mark. 2004, 21, 203-217. [CrossRef]

37. PwC Report: CSR Trends. 2010. Available online: http://www.rendircuentas.org/wp-content/uploads/2010/12/csr-trends-20 10-09.pdf (accessed on 6 December 2021).

38. KPMG Report: The Tima Has Come. The KPMG Survey of Sustainability Reporting. 2020. Available online: https://assets.kpmg/ content/dam/kpmg/be/pdf/2020/12/The_Time_Has_Come_KPMG_Survey_of_Sustainability_Reporting_2020.pdf (accessed on 6 December 2021).

39. KPMG Report: Społeczna Odpowiedzialność Biznesu, Fakty a Opinie. CSR Oczami Dużych i Średnich Firm w Polsce. Available online: https: / /assets.kpmg/content/dam/kpmg/pdf/2016/03/Raport-Spoleczna-odpowiedzialnosc-biznesu-fakty-a-opinieKPMG-FOB-2014.pdf (accessed on 6 December 2021).

40. EFL Report: CSR w MŚP pod Lupa. Available online: https://efl.pl/wp-content/uploads/2019/10/Raport-EFL-o-CSR-2019-1.pdf (accessed on 6 December 2021).

41. Bansal, P. Evolving sustainably: A longitudinal study of corporate sustainable development. Strateg. Manag. J. 2005, 26, 197-218. [CrossRef]

42. Berrone, P.; Gomez-Mejia, L.R. Environmental performance and executive compensation: An integrated agency-institutional perspective. Acad. Manag. J. 2009, 52, 103-126. [CrossRef]

43. Bartikowski, B.; Walsh, G. Investigating mediators between corporate reputation and customer citizenship behaviors. J. Bus. Res. 2011, 64, 39-44. [CrossRef]

44. Cho, C.H.; Guidry, R.P.; Hageman, A.M.; Patten, D.M. Do actions speak louder than words? An empirical investigation of corporate environmental reputation. Account. Organ. Soc. 2012, 37, 14-25. [CrossRef]

45. Dangelico, R.M. Improving firm environmental performance and reputation: The role of employee green teams. Bus. Strateg. Environ. 2015, 24, 735-749. [CrossRef]

46. Okumus, F.; Kuyucak Sengur, F.; Koseoglu, M.A.; Sengur, Y. What do companies report for their corporate social responsibility practices on their corporate websites? Evidence from a global airline company. J. Hosp. Tour. Technol. 2020, 11, 385-405. [CrossRef]

47. Sahay, A. Environmental reporting by Indian corporations. Corp. Soc. Responsib. Environ. Manag. 2004, 11, 12-22. [CrossRef]

48. Boztepe, A. Green marketing and its impact on consumer buying behavior. Eur. J. Econ. Polit. Stud. 2012, 5, 5-21.

49. Haws, K.L.; Winterich, K.P.; Naylor, R.W. Seeing the world through GREEN-tinted glasses: Green consumption values and responses to environmentally friendly products. J. Consum. Psychol. 2014, 24, 336-354. [CrossRef]

50. Mandliya, A.; Varyani, V.; Hassan, Y.; Akhouri, A.; Pandey, J. What influences intention to purchase sustainable products? impact of advertising and materialism. Int. J. Product. Perform. Manag. 2020, 69, 1647-1669. [CrossRef]

51. Han, H.; Al-Ansi, A.; Chi, X.; Baek, H.; Lee, K.S. Impact of environmental CSR, service quality, emotional attachment, and price perception on word-of-mouth for full-service airlines. Sustainability 2020, 12, 3974. [CrossRef]

52. Sun, H.; Rabbani, M.R.; Ahmad, N.; Sial, M.S.; Guping, C.; Zia-Ud-din, M.; Fu, Q. CSR, Co-creation and green consumer loyalty: Are green banking initiatives important? A moderated mediation approach from an emerging economy. Sustainability 2020, 12, 10688. [CrossRef]

53. Kantar Polska Report: Ziemianie Atakuja! Available online: https://odpowiedzialnybiznes.pl/wp-content/uploads/2019/09/ ziemianie-atakuja.pdf (accessed on 6 December 2021).

54. Zhang, X.; Dong, F. Why do consumers make green purchase decisions? Insights from a systematic review. Int. J. Environ. Res. Public Health 2020, 17, 6607. [CrossRef] [PubMed]

55. Bohdanowicz, P. Environmental awareness and initiatives in the Swedish and Polish hotel industries-survey results. Int. J. Hosp. Manag. 2006, 25, 662-682. [CrossRef]

56. Lynes, J.K.; Dredge, D. Going green: Motivations for environmental commitment in the airline industry. A case study of Scandinavian Airlines. J. Sustain. Tour. 2006, 14, 116-138. [CrossRef]

57. Kooskora, M. Building capacity for CSR through supportive initiatives in Estonia. In Key Initiatives in Corporate Social Responsibility. CSR, Sustainability, Ethics \& Governance; Idowu, S., Ed.; Springer: Cham, Switzerland, 2016; pp. 243-260, ISBN 978-3-319-21640-9.

58. Radecki, W. Ochrona Środowiska w Polskim, Czeskim i Słowackim Prawie Karnym. Studium Prawnoporównawcze; Wolters Kluwer Polska SA: Warszawa, Poland, 2013; ISBN 978-83-264-4261-2. 
59. Zębek, E.; Kulbacka-Burakiewicz, N. Odpowiedzialność karna za przestępstwo zanieczyszczenia środowiska-Wybrane aspekty. Stud. Prawnoustr. 2019, 381-391. [CrossRef]

60. Mobile Institute Green Generation. Wspólnie na Rzecz Ziemi. Available online: https: / / eizba.pl/raport-green-generation-2020 -green-e-commerce/ (accessed on 10 January 2021).

61. CCIFP Raport z 4. Edycji Badania "CSR w Praktyce-Barometr Francusko-Polskiej Izby Gospodarczej". Available online: https:/ / www.ccifp.pl/komunikacja/publikacje/p/publication/barometr-csr-2019.html (accessed on 10 January 2021).

62. Doś, A. "Leading by Example"-Are state-owned enterprises leaders of corporate social responsibility? Evidence from Poland. In Global Versus Local Perspectives on Finance and Accounting. ACFA 2018; Prochazka, D., Ed.; Springer International Publishing: New York, NY, USA, 2019; pp. 319-328. ISBN 978-3-030-11851-8.

63. Panchenko, Y.; Kiriakova, M. Practices of Corporate Social Responsibility in Ukraine. Nierówności Społeczne a Wzrost Gospod. 2016, 48, 197-208. [CrossRef]

64. Rivera, J.J.; Bigne, E.; Curras-Perez, R. Efectos de la responsabilidad social corporativa sobre la satisfacción del consumidor con la marca. Spanish J. Mark. ESIC 2016, 20, 104-114. [CrossRef]

65. Becker-Olsen, K.L.; Cudmore, B.A.; Hill, R.P. The impact of perceived corporate social responsibility on consumer behavior. J. Bus. Res. 2006, 59, 46-53. [CrossRef]

66. Vlachos, P.A.; Tsamakos, A.; Vrechopoulos, A.P.; Avramidis, P.K. Corporate social responsibility: Attributions, loyalty, and the mediating role of trust. J. Acad. Mark. Sci. 2009, 37, 170-180. [CrossRef]

67. Chan, T.J.; Saad, S. Predictors of consumers purchase intention through triple bottom line corporate social responsibility practices: A study of the branded coffee retailing industry. J. Arts Soc. Sci. 2019, 3, 47-59.

68. Öberseder, M.; Schlegelmilch, B.B.; Murphy, P.E. CSR practices and consumer perceptions. J. Bus. Res. 2013, 66, 1839-1851. [CrossRef]

69. Lu, L.; Bock, D.; Joseph, M. Green marketing: What the millennials buy. J. Bus. Strategy 2013, 34, 3-10. [CrossRef]

70. D'Souza, C.; Taghian, M.; Lamb, P. An empirical study on the influence of environmental labels on consumers. Corp. Commun. An. Int. J. 2006, 11, 162-173. [CrossRef]

71. Young, W.; Hwang, K.; McDonald, S.; Oates, C.J. Sustainable consumption: Green consumer behaviour when purchasing products. Sustain. Dev. 2010, 18, 20-31. [CrossRef]

72. Liu, X.; Pan, Y. A study of carbon emissions during a tour: A case study of a four-day guided tour in Guilin, China. J. Hosp. Tour. Manag. 2016, 29, 80-87. [CrossRef]

73. Bang, H.-K.; Ellinger, A.E.; Hadjimarcou, J.; Traichal, P.A. Consumer concern, knowledge, belief, and attitude toward renewable energy: An application of the reasoned action theory. Psychol. Mark. 2000, 17, 449-468. [CrossRef]

74. Policarpo, M.C.; Aguiar, E.C. How self-expressive benefits relate to buying a hybrid car as a green product. J. Clean. Prod. 2020, 252, 119859. [CrossRef]

75. FOB Raport Forum Odpowiedzialnego Biznesu: Odpowiedzialny Biznes w Polsce. Dobre Praktyki. 2019. Available online: https://www.forbes.pl/biznes/produkcja-i-sprzedaz-rowerow-w-polsce/11xh481 (accessed on 21 October 2020 ).

76. McCright, A.M.; Xiao, C. Gender and environmental concern: Insights from recent work and for future research. Soc. Nat. Resour. 2014, 27, 1109-1113. [CrossRef]

77. Öberseder, M.; Schlegelmilch, B.B.; Gruber, V. "Why don't consumers care about CSR?": A qualitative study exploring the Role of CSR in consumption decisions. J. Bus. Ethics 2011, 104, 449-460. [CrossRef]

78. Okros, A. Generational theory and cohort analysis BT. In Harnessing the Potential of Digital Post-Millennials in the Future Workplace; Okros, A., Ed.; Springer International Publishing: Cham, Switzerland, 2020; pp. 33-51. ISBN 978-3-030-25726-2.

79. Al-Aomar, R.; Hussain, M. An assessment of adopting lean techniques in the construct of hotel supply chain. Tour. Manag. 2018, 69, 553-565. [CrossRef]

80. Rhein, S.; Schmid, M. Consumers awareness of plastic packaging: More than just environmental concerns. Resour. Conserv. Recycl. 2020, 162, 105063. [CrossRef]

81. Topić, M.; Bridge, G.; Tench, R. Mirroring the zeitgeist: An analysis of CSR policies in the UK's food, soft drink and packaging industries. J. Glob. Responsib. 2020. ahead of print. [CrossRef]

82. Berthiaume, D. Survey: Generations Differ on Importance of Sustainability |Chain Store Age. Available online: https:// chainstoreage.com/survey-generations-differ-importance-sustainability (accessed on 6 February 2021).

83. Tapper, J. Move Over, Millennials. Boomers are UK's Greenest Generation I Environment I The Guardian. Available online: https: / / www.theguardian.com/environment/2020/nov/22/move-over-millennials-boomers-are-uks-greenest-generation (accessed on 6 February 2021).

84. Accenture \& Fashionbiznes.pl Raport: Jak Kupuje Generacja Z. Available online: https://www.accenture.com/pl-pl/insights/ retail/report-as-buys-generation-from-2019 (accessed on 1 January 2021).

85. Su, C.-H.; Tsai, C.-H.; Chen, M.-H.; Lv, W.Q. Sustainable food market generation z consumer segments. Sustainability 2019, 11, 3607. [CrossRef]

86. Blombäck, A.; Wigren, C. Challenging the importance of size as determinant for CSR activities. Manag. Environ. Qual. An. Int. J. 2009, 20, 255-270. [CrossRef] 
87. Nielsen Report: Ekologia i Naturalność. Available online: https://forumbranzykosmetycznej.pl/wp-content/uploads/2019/10/ 1_NIELSEN.pdf (accessed on 6 December 2021).

88. Wilk, I. Istota Marketingu Ekologicznego w Warunkach Zrównoważonego Rozwoju. Zesz. Nauk. Politech. Ślaskiej. Organ. Zarządzanie 2018, 118, 9. 